\title{
Input from a chemosensory organ, the osphradium, does not mediate aerial respiration in Lymnaea stagnalis
}

\author{
Vikram Karnik, Sarah Dalesman, Ken Lukowiak*
}

Hotchkiss Brain Institute, Faculty of Medicine, University of Calgary, 3330 Hospital Drive NW, Calgary, Alberta T2N 4N1, Canada

\begin{abstract}
Breathing behaviour is driven by chemosensory information sensed by oxygen or carbon dioxide receptors that detect the level of these substances either internally or in the external environment. In terrestrial species, oxygen chemosensation is primarily through internal sensors, whereas in aquatic animals, such as the pond snail Lymnaea stagnalis, external oxygen chemoreceptors are thought to be more important, due to the low partial pressure of oxygen in water. It has been hypothesized that an external chemosensory organ, the osphradium, modulates aerial respiratory behaviour in hypoxic conditions in Lymnaea, but recent data indicate that this may not be the case. In the present study, we removed the input from this organ to the central nervous system and measured aerial respiratory behaviour. We assessed breathing behaviour prior to surgery and then operated on the snails, severing either (1) the osphradial nerve proximal to the osphradium or (2) the right internal parietal (RIP) nerve into which the osphradial nerve, in addition to other axons from the lung/pneumostome area, projects. We also used a sham-operated control group. Severing either the osphradial or RIP nerve did not alter breathing behaviour in eumoxic or hypoxic conditions relative to the behaviour prior to surgery or that of sham-operated animals. Therefore, we conclude that input from the osphradium does not drive aerial respiratory behaviour.
\end{abstract}

KEY WORDS: Lymnaea $\cdot$ Osphradium $\cdot$ Aerial respiration $\cdot$ Hypoxia $\cdot$ Chemosensory

\section{INTRODUCTION}

Respiration is an essential process for all living animals. Typically, the initiation and modulation of breathing patterns depends on chemosensory input to the neurons that control respiratory behaviour (Feldman et al. 2003). Depending on the animal, chemoreceptors provide essential information regarding $\mathrm{O}_{2}, \mathrm{CO}_{2}$, and $\mathrm{pH}$ levels (Nattie 1998, Ballantyne \& Scheid 2001). These chemoreceptors can be found both peripherally and internally, depending on the species. Aquatic animals typically rely more heavily on external oxygen receptors because of the lack of a high, consistent partial pressure of oxygen in water in comparison to air, whereas land animals rely on internal receptors to regulate breathing (Taylor et al. 1999).

The freshwater pulmonate snail Lymnaea stagnalis is a bimodal breather, which means that they are able to satisfy their oxygen requirements either cutaneously or aerially using a basic lung (Syed et al. 1990, Lukowiak et al. 1996, Hermann \& Bulloch 1998). They inhabit slow-moving or stagnant water, where dissolved oxygen frequently drops to hypoxic levels (data not shown), preventing the snail from obtaining an adequate oxygen supply via diffusion across its skin. When hypoxic conditions occur, whether in the laboratory or in the field, aerial respiratory behaviour is significantly increased relative to that during higher oxygen conditions (Lukowiak et al. 1996, 1998). 
It has been proposed that an increase in aerial respiration is primarily due to the snail sensing the oxygen conditions in the water using external chemoreceptors (Inoue et al. 2001). More specifically, Bell et al. (2007) concluded that the external chemosensory organ known as the osphradium was the driving force behind hypoxic aerial respiratory patterns (Bell et al. 2007). Whether the osphradium plays a role in mediating or modulating aerial respiration is not completely clear in the literature. Wedemeyer \& Schild (1995) reported in their studies no response to hypoxia in 9 of 20 preparations. In the 11 preparations that showed a response to hypoxia, the change in response was variable. In some of the preparations, there was an increase in the recruitment of single units, while in other preparations, there was a suppression of single-unit activity. The authors concluded that the response of the neurons in the osphradium to hypoxia was variable. In contrast, they found a much more reliable response to an increase in partial pressure of $\mathrm{CO}_{2}\left(\mathrm{pCO}_{2}\right)$. In another study, the data presented by Kamardin et al. (2001) clearly show that the cells in the osphradium function to detect changes in osmolality, $\mathrm{NaCl}$ reception, and certain amino acids (e.g. L-aspartate).

Severing the nerve connecting the osphradium to the central nervous system (CNS) was thought to significantly reduce the time spent engaging in aerial respiration and the number of breaths taken in hypoxic conditions (Bell et al. 2007). However, our recent results suggest that although the osphradium may play a role in oxygen detection (Wedemeyer \& Schild 1995, Kamardin et al. 2001), severing the osphradial nerve does not affect aerial respiration during hypoxia when assessed using the number of breathing attempts during training (Il-Han et al. 2010, Dalesman et al. 2011). We therefore wanted to confirm whether or not severing the osphradial nerve altered basic aerial respiration behaviour. Because snails demonstrate high levels of individual variability in aerial respiratory behaviour, both between measurements on the same animal and also among different individuals, we wanted to systematically assess how respiration may be altered after severing the osphradial nerve. Therefore, we measured aerial respiratory behaviour in the same individual before and after cutting the nerve on multiple occasions during both eumoxia $\left(\sim 100 \% \mathrm{O}_{2}\right)$ and hypoxia $\left(\leq 5 \% \mathrm{O}_{2}\right)$. Aerial respiratory behaviour during both eumoxia and hypoxia was measured on 3 separate days prior to surgery, using the same snails in eumoxic and hypoxic conditions, and on an additional 3 separate days following the surgery. We tested 3 separate groups of snails: (1) sham surgery; (2) surgery in which just the osphradial nerve proximate to the osphradium was severed; and (3) surgery in which the right internal parietal (RIP) nerve was severed. The RIP nerve receives input from the osphradial nerve in addition to other inputs from the pneumostome/lung area (Bullock \& Horridge 1965, De Vlieger 1968, Cook 1975). By comparing breathing behaviour within the same animal before and after surgery, we were able to easily identify any change in aerial respiratory behaviour as a result of the specific surgery, independent of the highly variable baseline breathing activity.

\section{MATERIALS AND METHODS}

Adult Lymnaea stagnalis, from a laboratory strain originating from wild snails collected in the 1950s from canals in a polder near Utrecht, were used to perform all of the experiments. The snails were reared in the University of Calgary's Biological Sciences building in artificial pond water $\left(\sim 0.25 \mathrm{~g} \mathrm{l}^{-1}\right.$ Instant Ocean ${ }^{\circledR}$, Aquarium Systems) with added calcium carbonate to maintain sufficient calcium levels ( $\geq 50 \mathrm{mg} \mathrm{l}^{-1}$ ). Additional access to sterilized cuttlefish Sepia officinalis bone was also provided to maintain calcium levels (Hermann et al. 2009). The animals were fed ad libitum with lettuce and Aquamax-carnivorous Grower 600 trout pellets (Purina Mills). They were then transferred to the laboratory $1 \mathrm{wk}$ prior to the experiments and maintained in oxygenated artificial pond water $\left(0.26 \mathrm{~g} \mathrm{l}^{-1}\right.$ Instant Ocean $\left.{ }^{\circledR}\right)$ containing calcium sulphate dehydrate $\left(80 \mathrm{mg} \mathrm{l}^{-1}\right)$ at room temperature $\left(\sim 20^{\circ} \mathrm{C}\right)$. The snails were kept at a density of 1 snail $1^{-1}$ and were fed romaine lettuce ad libitum.

\section{Surgical procedure}

Three groups of animals were used for these experiments: animals that had the RIP nerve severed (identified as 'RIP'), animals in which the osphradial nerve was severed (identified as 'cut'), and animals that were put through a sham operation (identified as 'sham'). The snails were first anaesthetised using iced pond water and subsequently injected with $2 \mathrm{ml}$ of $50 \mathrm{mM} \mathrm{MgCl}$ via the foot into the haemocoel to prevent withdrawal into the shell. The animals were then placed into a dissection dish, and a small slit was made in the skin adjacent to the osphradium to access the nerves. In the sham animals, the small slit 
was made, but the nerve was left intact. In the cut animals, the nerve was severed proximal to the osphradium, whereas in the RIP animals, the cut was made more distal to the osphradium after the osphradial nerve had anastomosed with the larger RIP nerve. The animals recovered rapidly from all of the procedures, no further action was required to close the incision, and their behaviour appeared normal within an hour.

\section{Breathing measurements}

We measured aerial respiratory behaviour (see below), in both eumoxic $\left(\sim 100 \%\left[\mathrm{O}_{2}\right]\right)$ and hypoxic $\left(<5 \%\left[\mathrm{O}_{2}\right]\right)$ conditions for $0.5 \mathrm{~h}$. To measure breathing rate under eumoxic conditions, we aerated $500 \mathrm{ml}$ of pond water in a 11 beaker for $20 \mathrm{~min}$. To assess breathing rates during hypoxia, we made the water hypoxic by bubbling nitrogen through $500 \mathrm{ml}$ of pond water in a 11 beaker for 20 min before the observation period. Bubbling was continued at a reduced level throughout the observation period to maintain relative oxygen conditions. In all of the breathing observation sessions (eumoxic and hypoxic), the snails were placed into the beaker and allowed to acclimate for $10 \mathrm{~min}$ prior to observation. This acclimation was then followed by a 30 min observation period during which the aerial respiration behaviour was recorded, noting the total breathing time, number of breaths, and duration of each breath. Following each breathing observation session, the snails were returned to their home eumoxic aquaria.

Breathing behaviour during both hypoxia and eumoxia was recorded for each animal on each of 6 observation days (Fig. 1). Whether an individual snail experienced eumoxic or hypoxic conditions initially was randomly allocated on each day, with a $1 \mathrm{~h}$ break between breathing tests. After the measurements on the third day, the animals were randomly allocated to
1 of 3 surgical groups, sham, osphradially cut or RIP cut (see above for surgical details). Aerial respiration behaviour was then measured 3,5 and $7 \mathrm{~d}$ postsurgery in both eumoxic and hypoxic conditions. The observer during this post-surgery period was blind to the type of surgery that each animal had received.

\section{Statistical analysis}

The data were analysed using repeated-measures ANOVA in SPSS 17.0. Homogeneity of variance was assessed using Mauchly's test for sphericity, and where sphericity could not be assumed, the more conservative Greenhouse-Geisser correction was used (Greenhouse \& Geisser 1959). Three variables were analysed to assess aerial respiration behaviour: total breathing time over $30 \mathrm{~min}$, total number of individual breaths in $30 \mathrm{~min}$, and the average length of each breath by an individual snail. The withinsubject factor was the repeated measure of each variable at separated time points before and after the surgical procedures. The within-subject comparison allowed us to test for any directional response in breathing behaviour before and after surgery, even if different animals exhibited very different magnitudes in their response. The between-subject factors were the oxygen conditions (eumoxic vs. hypoxic) and whether the snails underwent the sham, osphradial cut, or RIP cut surgical procedure.

\section{RESULTS}

As noted from our previous work (K. Lukowiak pers. obs.), we found high levels of variability in aerial respiratory behaviour, both within and among individuals. To demonstrate this variability, we will discuss the variation in total breathing time (TBT). In eumoxic conditions, the average standard deviation

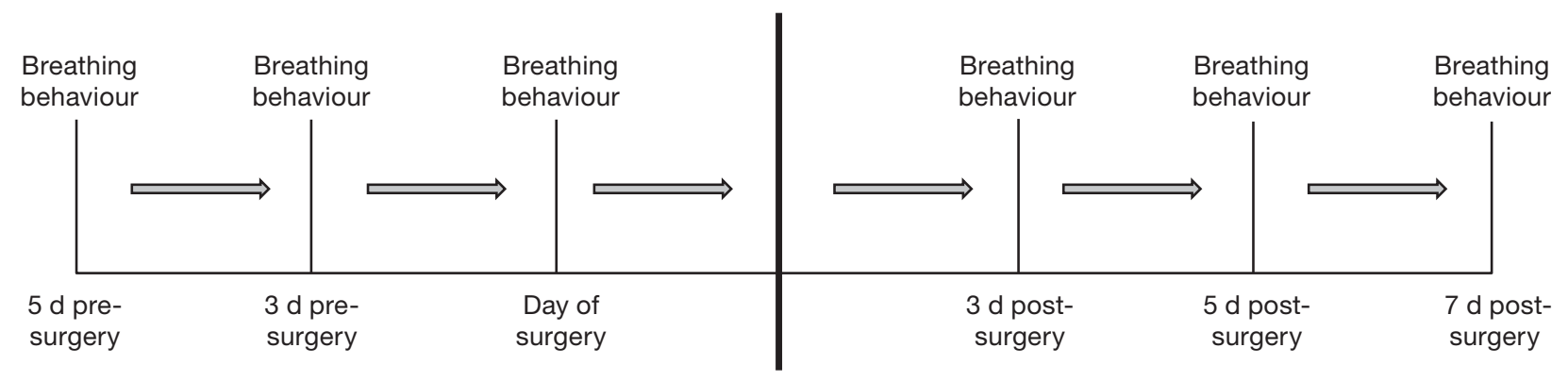

Surgical treatment

Fig. 1. Lymnaea stagnalis. Timeline of conducted experiments. The same group of snails was used for breathing measurements pre- and post-surgery ( $\mathrm{n}=20$ per surgical group) 
(SD) within measurements from the same individual (SD: $\pm 37 \mathrm{~s}$ ) was lower than within a single time period among individuals (SD: $\pm 44 \mathrm{~s}$ ). Comparing the maximum and minimum TBT, we found significant variation within individuals, from animals that showed little variation (e.g. min: $0 \mathrm{~s}$; max: $8 \mathrm{~s}$; difference: $8 \mathrm{~s}$ ) to those that showed a large difference between measurements (e.g. min: $0 \mathrm{~s}$; max: $187 \mathrm{~s}$; difference: $187 \mathrm{~s}$ ). However, we found that the least difference between maximum and minimum measurements was much greater between individual differences within a single time point, for example, at $5 \mathrm{~d}$ post-surgery (e.g. min: $0 \mathrm{~s}$; max: $152 \mathrm{~s}$; difference: $152 \mathrm{~s}$ ), but there was no difference in the maximum difference between these measurements (e.g. min: $0 \mathrm{~s}$; max: $187 \mathrm{~s}$; difference: 187 s) at $3 \mathrm{~d}$ pre-surgery and $7 \mathrm{~d}$ post-surgery. Under hypoxic conditions, we saw a similar pattern. The within-individual variation across all 6 measurements (SD: $\pm 178 \mathrm{~s}$ ) was lower than the average betweenindividual variation within a single time point (SD: $\pm 195 \mathrm{~s}$ ). The within-individual minimum and maximum breathing rates varied among those animals that showed little difference between time points (e.g. min: $212 \mathrm{~s}$; max: $381 \mathrm{~s}$; difference $169 \mathrm{~s}$ ) and those that showed considerable difference between time points (e.g. min: $46 \mathrm{~s}$; max: $939 \mathrm{~s}$; difference: $893 \mathrm{~s}$ ). However, similar to our comparison of the standard deviation, this variation was more substantial among individuals within a single time point. The least difference between the minimum and maximum TBT was among individuals at the time point $5 \mathrm{~d}$ postsurgery (e.g. min: $13 \mathrm{~s}$; max: $610 \mathrm{~s}$; difference $597 \mathrm{~s}$ ), and the greatest difference was during our initial time period $5 \mathrm{~d}$ pre-surgery (e.g. min: $12 \mathrm{~s}$; max: $939 \mathrm{~s}$; difference: 927 s). By using a repeated-measures design in our analyses, we were able to assess whether there was any trend in aerial breathing behaviour despite a high level of variance within this trait.

The TBT was significantly higher under hypoxic conditions than under eumoxia (Fig. 2a,b; main effect of oxygen concentration: $F_{1,114}=318.354, \mathrm{p}<0.001$ ) . The response to oxygen concentration did not differ depending on the breathing session $\left(F_{4.6,524.6}=0.153\right.$, $\mathrm{p}=0.979)$, surgery $\left(F_{2,114}=0.384, \mathrm{p}=0.682\right)$, or interaction between these 2 factors $\left(F_{9,2,524.6}=0.251, \mathrm{p}=\right.$ 0.987 ). There was also no significant overall effect of the time at which breathing was measured relative to the surgical procedure on the TBT $\left(F_{4.6,524.6}=0.078\right.$, $\mathrm{p}=0.996)$, type of surgical procedure $\left(F_{2,114}=0.386\right.$, $\mathrm{p}=0.680$ ), or interaction between these 2 factors $\left(F_{9.2,524.6}=0.215, \mathrm{p}=0.995\right)$.

The total number of breaths was significantly higher in hypoxic conditions than in eumoxia (Fig. 2c, d; main effect of oxygen concentration: $F_{1,114}=397.040, \mathrm{p}<$ 0.001). The response to oxygen concentration did not differ depending on the breathing session $\left(F_{5,570}=\right.$ $0.557, \mathrm{p}=0.733)$, surgery $\left(F_{2,114}=0.046, \mathrm{p}=0.955\right)$, or interaction between these 2 factors $\left(F_{10,570}=0.377, \mathrm{p}=\right.$ 0.957). There was also no significant overall effect of the time at which breathing was measured relative to the surgical procedure on the average number of breaths $\left(F_{5,570}=0.443, \mathrm{p}=0.818\right)$, type of surgical procedure $\left(F_{2,114}=0.728, \mathrm{p}=0.485\right)$, or interaction between these 2 factors $\left(F_{10,570}=0.164, \mathrm{p}=0.998\right)$.

The average breath duration was significantly higher under hypoxic conditions than under eumoxia (Fig. 2e, $\mathrm{f}_{;}$main effect of oxygen concentration: $\left.F_{1,114}=361.301, \mathrm{p}<0.001\right)$. The response to oxygen concentration did not differ depending on the breathing session $\left(F_{5,570}=1.293, \mathrm{p}=0.265\right)$, surgery $\left(F_{2,114}=0.084, \mathrm{p}=0.919\right)$, or interaction between these 2 factors $\left(F_{10,570}=0.325, \mathrm{p}=0.975\right)$. There was also no significant overall effect of the time at which breathing was measured relative to the surgical procedure on the average number of breaths $\left(F_{5,570}=\right.$ $0.222, \mathrm{p}=0.953)$, type of surgical procedure $\left(F_{2,114}=\right.$ 2.386, $\mathrm{p}=0.097$ ), or interaction between these 2 factors $\left(F_{10,570}=0.598, \mathrm{p}=0.816\right)$.

\section{DISCUSSION}

The structure known as the osphradium has been shown to be a primary sensory organ by which Lymnaea detects chemosensory information in its environment (Wedemeyer \& Schild 1995, Kamardin et al. 2001). The osphradium was implicated in the control of aerial respiration based on a response in osphradial cells in a semi-intact preparation to low oxygen conditions and apparent changes in aerial respiratory behaviour when the osphradial nerve was severed (Bell et al. 2007). Here, we found no evidence to support a role of the osphradium in controlling aerial respiratory behaviour in either high (eumoxic) or low (hypoxic) oxygen conditions. Indeed, interrupting the input from the osphradial nerve alone or from both the osphradial nerve and the right internal parietal nerve had no effect on aerial breathing behaviour. However, sensory input from the pneumostome area, which possibly acts to control aerial respiratory behaviour, can still reach the CNS via other neuronal pathways (Bullock \& Horridge 1965, De Vlieger 1968, Cook 1975).

Our results are in stark contrast to the data presented by Bell et al. (2007), in which cutting the osphradial nerve significantly reduced total breath- 

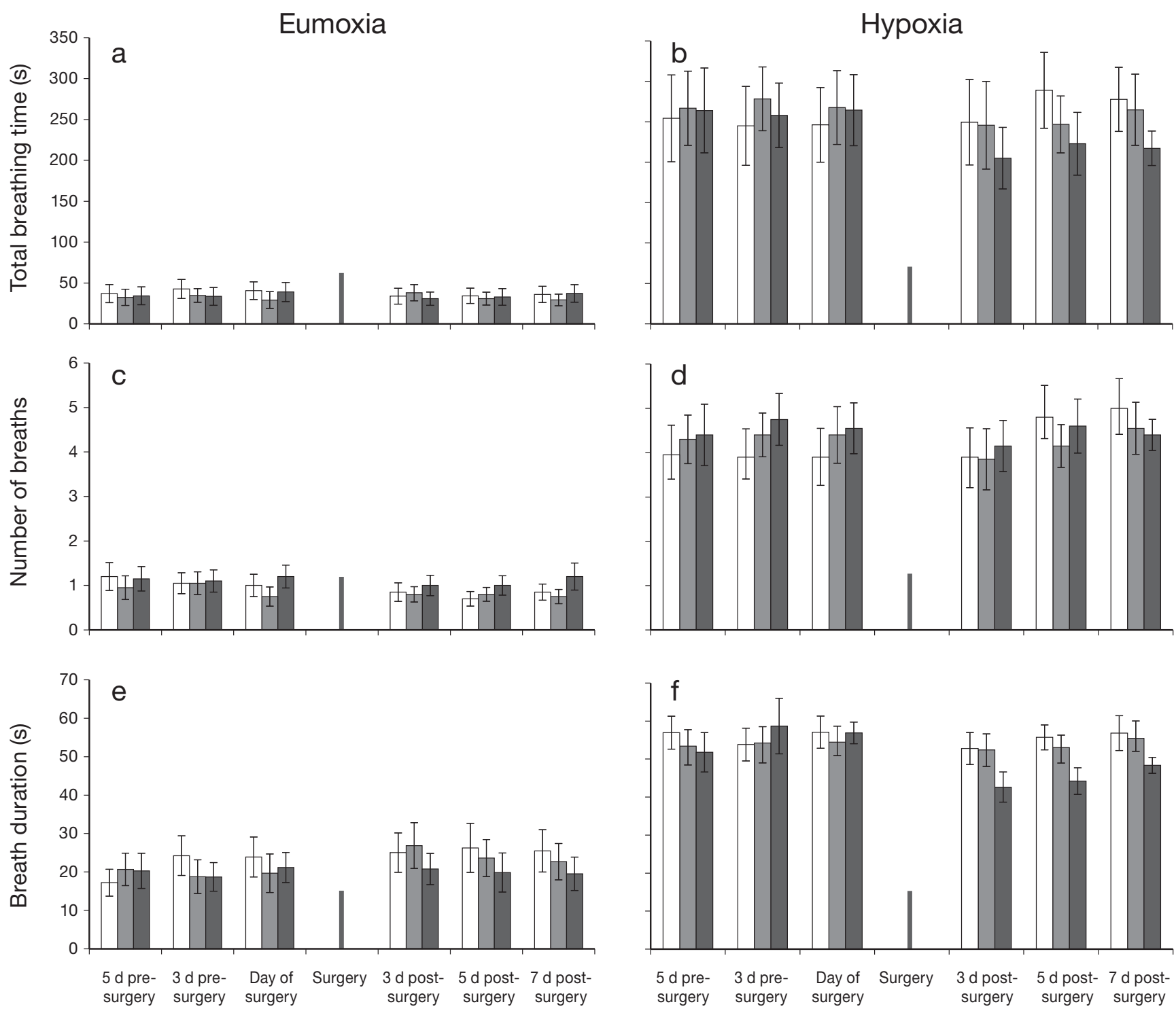

Fig. 2. Lymnaea stagnalis. Breathing behaviour of snails pre- and post-surgery over 30 min under eumoxic or hypoxic conditions. $(\mathrm{a}, \mathrm{b})$ Total breathing time, $(\mathrm{c}, \mathrm{d})$ number of breaths, and $(\mathrm{e}, \mathrm{f})$ average breath duration before and after surgery under $(\mathrm{a}, \mathrm{c}, \mathrm{e})$ eumoxic or $(\mathrm{b}, \mathrm{d}, \mathrm{f})$ hypoxic conditions. Post-surgery groups are classified as: sham (white bars), osphradial nerve cut (light grey) or right internal parietal nerve cut (dark grey) (see 'Materials and methods: Surgical procedure' for more details). Values are mean $\pm \mathrm{SEM}, \mathrm{n}=20$ for each group

ing time under hypoxic conditions. To explain this difference in experimental results, we must consider an important factor regarding aerial respiratory behaviour. As shown here, there is great variability among individual snails and their breathing patterns. For example, in our first breathing observation data, $5 \mathrm{~d}$ prior to any type of operation, the maximum time spent breathing under hypoxic conditions by an individual snail in the 30 min time period was $939 \mathrm{~s}$, while the minimum time of an individual snail in the same hypoxic conditions was $12 \mathrm{~s}$. For this reason, we used within-individual comparisons before and after surgery, which would indicate if consistent patterns of increase or decrease in breathing behaviour occurred following surgery irrespective of the starting point for each animal. In the previous work by Bell et al. (2007), comparisons were not made between the same snails before and after surgery. Rather, comparisons were made between different snails forming the cut vs. control groups. In addition, a small sample size was used for each group $(n=7)$. Thus, it is highly likely that the behaviour of 1 or 2 animals could have given a false positive result. Our procedure tested the same snail both before and after the surgery and used a larger group size ( $\mathrm{n}=20$ for each surgery treatment group). Therefore, our re- 
sults provide a more accurate assessment of whether the osphradium is involved in modulating aerial respiration. In addition, our data here are consistent with previous published results (Wedemeyer \& Schild 1995) of direct electrophysiological recordings from the osphradium, which indicate great variability in whether the osphradium responds to a hypoxic stimulus. While the osphradium may not be necessary for aerial respiration, it may be used to modulate cutaneous respiration. For example, the flow of haemolymph in the tentacles has been shown to increase in response to low oxygen levels in the environment (Kerney 1999). It is possible that this change in haemolymph flow may be mediated by the osphradial input that would alter, for example, the activity of neurons controlling heart rate and blood pressure.

If the osphradial nerve and RIP nerve are not required to mediate normal breathing patterns, what structures are involved? Maintaining oxygen levels is undoubtedly a vital mechanism for all animals, and therefore, chemosensation of oxygen and/or carbon dioxide is of vital importance (Feldman et al. 2003). However, the mechanisms by which organisms detect hypoxic conditions can vary significantly (Taylor et al. 1999). In mammals, respiratory control appears to be primarily internalised, with oxygen sensors located in the branches of the carotid arteries and the aortic arch (Lopez-Barneo et al. 2010, Teppema \& Dahan 2010), and carbon dioxide levels are monitored in the cerebrospinal fluid (Teppema \& Dahan 2010). But because oxygen levels are fairly constant in environments for air-breathing animals, carbon dioxide receptors that measure the internal levels of this gas are of greater significance (Taylor et al. 1999). In aquatic animals, there is a greater reliance on oxygen-sensitive chemoreceptors due to the lower partial pressure of oxygen in aquatic environments and the fact that oxygen levels in the water can vary significantly (Lopez-Barneo et al. 2010). These chemoreceptors can primarily be found peripherally near the gills of fish as well as internally in the dorsal aorta (Burleson et al. 1992). In addition to differences among classes of organisms, differences can be seen between life stages dependant on the environment they occupy. For example, while bullfrog larvae have functional oxygen receptors on gill arches, receptors situated at the bifurcation of the internal and external carotid arteries take over the primary functional role in adults (Stuesse et al. 1984). Clearly, there are several ways in which animals can sense the oxygen levels in their environment, which are likely to relate to habitat type.
Lymnaea stagnalis lives in a highly variable environment in terms of oxygen saturation and has been shown to use primarily peripheral oxygen receptors to drive aerial respiratory behaviour (Inoue et al. 2001). This characteristic is in contrast to the terrestrial snail Helix aspersa, which has primarily internal carbon dioxide chemoreceptors (Erlichman \& Leiter 1993, 1994). Although classified as an aquatic species, Lymnaea maintains a lung and uses it to perform aerial respiration. This allows Lymnaea to exploit environmental niches that are not readily available to 'purely' terrestrial or aquatic species. It also must be remembered that $L$. stagnalis evolved fairly recently from a terrestrial form and maintains some terrestrial characteristics, including eyes that are well adapted for vision in air (Gál et al. 2004). Hence, it is likely that although peripheral receptors have been shown to be sufficient to drive aerial respiratory behaviour (Inoue et al. 2001), both internal and external chemoreceptors may be present (i.e. features of both terrestrial and aquatic species), and these receptors may relay information back to the CNS through a variety of pathways. Further work is required to identify the sensory inputs controlling aerial respiration, but the simplicity of $L$. stagnalis as a model system is a great advantage, especially because the neural components of the central pattern generator of aerial respiration have been experimentally elucidated (Syed et al. 1990, 1992). Hence, it is completely feasible that this model system can help us identify the pathways by which sensory input controls aerial respiration, and when revealed, the pathways will enhance our understanding of how animals experiencing different oxygen habitats adapt sensory systems to cope.

Acknowledgements. Funding for this work was provided by a Natural Sciences and Engineering Research Council of Canada Undergraduate Student Research Award to V.K.; an Alberta Heritage Foundation for Medical Research fellowship from Alberta Innovates - Health Solutions supported S.D.; the Natural Sciences and Engineering Research Council of Canada supported K.L. and the laboratory.

\section{LITERATURE CITED}

Ballantyne D, Scheid P (2001) Central chemosensitivity of respiration: a brief overview. Respir Physiol 129:5-12

Bell HJ, Inoue T, Shum K, Luk C, Syed NI (2007) Peripheral oxygen-sensing cells directly modulate the output of an identified respiratory central pattern generating neuron. Eur J Neurosci 25:3537-3550

Bullock TH, Horridge GA (1965) Structure and function in the nervous systems of invertebrates, Vol 2. WH Freeman, San Francisco, CA 
Burleson ML, Smatresk NJ, Milsom WK (1992) Afferent inputs associated with cardioventilatory control in fish. In: Hoar WS, Randall DJ, Farrell AP (eds) Fish physiology: the cardiovascular system, Vol XXIIB. Academic Press, New York, NY, p 390-426

Cook A (1975) The withdrawal response of a freshwater snail (Lymnaea stagnalis L.). J Exp Biol 62:783-796

Dalesman S, Karnik V, Lukowiak K (2011) Sensory mediation of memory blocking stressors in the pond snail, Lymnaea stagnalis. J Exp Biol 214:2528-2533

De Vlieger TA (1967) An experimental study of the tactile system of Lymnaea stagnalis (L.). Neth J Zool 18:105-154

Erlichman JS, Leiter JC (1993) $\mathrm{CO}_{2}$ chemoreception in the pulmonate snail Helix apersa. Respir Physiol 93:347-363

Erlichman JS, Leiter JC (1994) Central chemoreceptor stimulus in the terrestrial, pulmonate snail Helix apersa. Respir Physiol 95:209-226

Feldman JL, Mitchell GE, Nattie EE (2003) Breathing: rhythmicity, plasticity, chemosensitivity. Annu Rev Neurosci 26:239-266

Gál J, Bobkova MV, Zhukov VV, Shepeleva IP, MeyerRuchow VB (2004) Fixed focal-length optics in pulmonate snails (Mollusca, Gastropoda): squaring phylogenetic background and ecophysiological needs (II). Invertebr Biol 123:116-127

Greenhouse SW, Geisser S (1959) On methods in the analysis of profile data. Psychometrika 24:95-112

$>$ Hermann PM, Bulloch AG (1998) Developmental plasticity of respiratory behavior in Lymnaea. Behav Neurosci 112: 656-667

Hermann PM, Genereux B, Wildering WC (2009) Evidence for age-dependent mating strategies in the simultaneous hermaphrodite snail, Lymnaea stagnalis (L.). J Exp Biol 212:3164-3173

Il-Han J, Janes T, Lukowiak K (2010) The role of serotonin in the enhancement of long-term memory resulting from predator detection in Lymnaea. J Exp Biol 213: 3603-3614

Inoue T, Haque Z, Lukowiak K, Syed NI (2001) Hypoxia-

Editorial responsibility: Marc Weissburg,

Atlanta, Georgia, USA induced respiratory patterned activity in Lymnaea originates at the periphery. J Neurophysiol 86:156-163

Kamardin NN, Shalanki Y, Sh.-Rozha K, Nozdrachev AD (2001) Studies of chemoreceptor perception in mollusks. Neurosci Behav Physiol 31:227-235

Kerney M (1999) Atlas of the land and freshwater molluscs of Britain and Ireland. B.H.\&A. Harley Ltd, Colchester

López-Barneo J, Nurse CA, Nilsson GE, Buck LT, Gassmann M, Bogdanova AY (2010) First aid kit for hypoxic survival: sensors and strategies. Physiol Biochem Zool 83: 753-763

> Lukowiak K, Ringseis E, Spencer G, Wildering W, Syed N (1996) Operant conditioning of aerial respiratory behaviour in Lymnaea stagnalis. J Exp Biol 199:683-691

> Lukowiak K, Cotter R, Westly J, Ringseis E, Spencer G, Syed $N$ (1998) Long-term memory of an operantly conditioned respiratory behaviour pattern in Lymnaea stagnalis. J Exp Biol 201:877-882

Nattie EE (1998) Central chemoreceptors, pH, and respiratory control. Wiley-Liss, New York, NY

Stuesse SL, Cruce WLR, Powell KS (1984) Organization within the cranial IX-X complex in ranid frogs: a horseradish peroxidase transport study. J Comp Neurol 222: 358-365

$>$ Syed NI, Bulloch AGM, Lukowiak K (1990) In vitro reconstruction of the respiratory central pattern generator of the mollusk Lymnaea. Science 250:282-285

Syed NI, Bulloch AGM, Lukowiak K (1992) The respiratory central pattern generator (CPG) of Lymnaea reconstructed in vitro. Acta Biol Hung 43:409-419

Taylor EW, Jordan D, Coote JH (1999) Central control of the cardiovascular and respiratory systems and their interactions in vertebrates. Physiol Rev 79:855-916

Teppema LJ, Dahan A (2010) Ventilatory response to hypoxia in mammals: mechanisms, measurement, and analysis. Physiol Rev 90:675-754

Wedemeyer H, Schild D (1995) Chemosensitivity of the osphradium of the pond snail Lymnaea stagnalis. J Exp Biol 198:1743-1754

Submitted: November 14, 2011; Accepted: February 16, 2012 Proofs received from author(s): April 26, 2012 